\title{
LIBRARY SKILL INSTRUCTION IN NIGERIAN ACADEMIC LIBRARIES
}

\author{
P. C. AZIAGBA AND E. H. UZOEZI \\ (Received 10, September 2009; Revision Accepted 8, February 2010)
}

\begin{abstract}
This survey was undertaken to portray the level of library involvement in library skill instruction courses taught in Nigerian tertiary institutions. Survey instrument used involved construction and distribution of questionnaires. These were distributed to professional librarians. The result of the data analysis indicate that library skill instruction courses are taught in most tertiary institutions in Nigeria, but this has not attained a firm footing. Time allocated for lectures and involvement in the mode of students' assessment is not determined by library instructors even when they are fully responsible for teaching the course. Allocation of time period for lectures and opportunity to be involved in assessment of students' performance in the course has not been fully granted to the library skill instructors. Information technology is not fully developed in most of these tertiary institutions. It is only $13 \%$ of all the universities surveyed in this report that have reached $70 \%$ compliance in information technology. Consequently, not much has been offered by library skill instructors on the application of information and communication technology (ICT) to their users. However, there is visible and encouraging beneficial impact of library instruction on library user. The library skill instructors have awakened the interest of the students towards library use. The much they have done in all areas has had visible and encouraging results.
\end{abstract}

KEY WORD: Library Skill, Library Use Instruction, Nigeria, Library in Tertiary Institutions,

\section{INTRODUCTION}

The University library plays a pivotal role in academic institutions. It is the centre of attraction and citadel of all meaningful learning and achievement when pursuing all academic programmes. It aids all research effort by users. The librarians who are entrusted with the responsibility to discharge the enormous potential embedded at these locations are usually worried when their effort at creating awareness for available resources are not fully realized.

The concept of library skill instruction has been introduced in the curriculum in order to cement this vacuum and draw user's attention to the need to acquire library skill knowledge so as to make effective use of library and information resources. Librarians seek for improved teaching techniques that will enable them deliver efficient library instructions both within the library (the practical component) and also in the classroom. The main purposes of library skill instruction is to enable the clientele acquire the skill on how to locate and retrieve information resources for use. To this end, library instruction sessions are usually tailored to specific information search needs of its clientele. This unique responsibility of academic libraries is intended to offer regular and in-depth instructional knowledge to library users.

Effort made to achieve this aim has not gone without problems. Most library users seem not to have recognized the significance and need for library skill instruction. This could be attributed to the fact that some users fail to appreciate the essence of library skill instruction as the base for their success when seeking for information. This will enable them experience a beneficial academic performance in their various subject discipline. This attitudinal position of users could be witnessed during most library skill instruction classes. The problem is further compounded by faculty teaching staff who often

P. C. Aziagba, University of Port Harcourt Library, Choba, Port Harcourt

E. H. Uzoezi, University of Port Harcourt Library, Choba, Port Harcourt 
insist on appointing teachers for this course themselves or drop the course altogether. They have remained indifferent in the effort to propagate teaching sessions successfully. I addition, most institutions do not undertake follow-up courses on library skill instruction after the first library orientation. The library skill instruction programme also has its internal problems. Among the professional library staff, there is the problem of who teaches the library instruction course particularly as it attracts little or no incentive. Then, there is the big divide in the library instruction circle over what should be included in the curriculum for library instruction sessions.

The ultimate aim of the library instruction is to improve students' information seeking ability. Most studies have shown that library instruction has some impact on students' attitude towards seeking information. Negative campus attitude and perception of library information literacy has been aggravated by the presence of electronic media - the internet. Many academic library users find the internet easier to use than the provisions at the library. Also, remote access to the resources of the library leads users away from the need for library instruction. Effort to put library instruction sessions in motion in universities has not been a waste. Major benefit of the instruction session is its effectiveness in exposing students to the use of new information resources and bringing to their memories what they have heard or used in the past. The knowledge gained sustains the students through their career period in the universities as well as in the future. This is because research skills have become a part of future job description. This paper aims at surveying library skill instruction in some Nigerian universities. This is to highlight the ways the librarians present the library instruction to their clientele. To identify the problems they encounter as well as their effort to sell the library to the academic communities.

\section{LITERATURE REVIEW}

Publications cited in this paper show the effectiveness of library skill instruction in creating awareness for the need to make users appreciate library services in tertiary institutions in Nigeria.

Lorenzen (2004) reviewed librarians teaching in classroom all over the world. The report stated that while some countries appear to have fairly well developed academic library skill instruction programmes, there is serious need for these services to be further developed. The level of development of academic library skill instruction in Nigeria is still low. Nwoye and Anafulu (1973) at the time of their report stated that there are very few well organized public libraries and even secondary school libraries. Since this situation has not seriously changed, it implies that most freshmen would not have used a library before enrolling in an institution of higher learning. The teaching of library skill instruction may therefore look strange to some library users as this may be their first encounter with lesson on how to locate information in the library.

While Adedigba (1990) wrote on library instruction programmes at a variety of agricultural tertiary institutions in Nigeria, Iroka (1990) gave the same overview for Nigerian medical schools. They observed the issues of library skill instruction efforts still at its infancy. Library skill instruction is a necessary provision and patrons would expect and desire a continuation of the programme in the $21^{\text {st }}$ century if adequate funding is provided for the library. Since the library is not totally in command of the finance, management involvement is very crucial. In another instance, Edem, Ani and Ocheibi (2009) recommended that library instruction be listed for newly admitted students while guided tours of library facilities are made compulsory for final year students. Have these students fully understood the place of the library in tertiary institutions? Enough exposure to the methods of information retrieval and literature search will make one encounter less problems in using the library resources. Oyewusi and Oyeboade (2009) observed that most Nigerian undergraduates view library as a place to borrow books and read lecture notes. They are still unaware of the rich content they can access through libraries' available resources. Adequate exposure to library resource use will eliminate students' graduation without being fully prepared for research in future.

In an empirical study, Emmons and Wanda (2002) concluded that library instruction made a small difference in the type of materials students chose and how they found them. They noticed an appreciable increase in library use. Some researchers believe that the effort made to tackle the problems of library skill instruction effectiveness should be based on characteristics of the user. Maybee (2006) studied the effect on users when the instruction is tailored towards the user information seeking behavior. The report came to the conclusion that a user - centered approach is very effective in delivering library instruction. To further support the influence of learning style, Costello, Lenholt and Stryker 
(2004) surveyed recent generation of college students and concluded that they have a learning style with identifiable characteristics. In order to capture them, learning instruction needs to be channeled towards their learning styles.

Since the allocation of classroom space is mainly dependent on provision from faculty, inadequate number of sessions is given for library skill instruction. When the library instructor is able to access more than allocated session the effect is remarkable. In such situation Gandlin (2004) reported that researchers who break their session instruction into shorter segments have achieved better learning result. To further establish workable relationship between the library and the faculty, Awale - Ale (2007) advised university library skill instructors (who interact with the faculties) to provide information sources that are relevant to the faculty needs and also create a process that works amicably with the faculty.

Most spectacular effect of library skill instruction is seen on its effect on information seeking behavior. In the report by Todd (2003), information seeking was defined as the interaction between people, data, knowledge and wisdom that fall under the rubric of knowledge and the diverse contexts in which they interact. Gross (2005) also referred to people that are deficient in information seeking skills as having difficulty in knowing when they need information. They equally do not know the value of the library in providing information and how to evaluate the sources they have found. Where the effects of library skill instruction have been utilized effectively, the emanating reports have been good. In a bibliometric analysis of influence of library skill instruction on students' project, Robinson and Schlegel (2004) found that library instruction had little impact on the type of sources cited. When the instructor enforced penalties as regards grading of the papers, the students cited more scholarly papers. Also, it appears that there is improvement on use of library resources when pressure is put on the students. Instructors mandating specific requirements for sources to be used had a very positive result. Horde (2000) also had an encouraging report when bibliographies from papers written by freshmen English students showed evidence of cited sources located through library data bases. Similarly, Hurst and Leonar (2007), still on the issue of term paper, put forward the idea that through analysis and comparism of bibliographies the sources used by the students could be visualized.
The presence of internet and easy with which people access information on the net, has its own problems on scholarship. Since this does not need much physical or mental effort, people access information on the web without making room for effective evaluation of what they have retrieved. Martin (2000) stated that option for quickly available information on the internet hinders the development of students' research skill as it provides only a small fraction of the information available on any given topic. The argument that the growth of the internet should be seen as development of a new research methodology has led to more students abandoning the use of library completely (O'Brien and Songa 2005). In a similar observation, Griffiths and Peter (2005) reported that over two - third of the students began their research on the internet rather than the academic library. Ghaphery (2002) in describing the Virginia Commonwealth Library had in mind making access to both library resources and the online resources more users friendly and easily accessible. In favour of information technology, Maness (2008) investigated library instruction delivered through video tutorial and established that the systems are indeed adequate alternative to live lectures. The issue of pre and post surveys was undertaken by Gong and Loomis (2009). Their result showed that follow-up instruction sessions had a significant impact on the students' library usage experience. However, the same experience was not found on the students, knowledge of the library resources. This will help design a more effective way to teach and interact to the millennial generation. In an intensive survey, Barbara et al (1993) suggested that library skill instruction classes be taught mainly by librarians who also do reference work. They could substitute teaching for reference desk hours for certain periods.

\section{METHODOLOGY}

In this study, the survey method was used. Questionnaire was constructed to deduct information from librarians who teach library skill in various university libraries in Nigeria.

The copies of the questionnaires were issued to librarians who attended the recently concluded 2009 national conference of the Nigerian Library Association held at Ibadan, Nigeria. This gathering offered a good opportunity where all the librarians who received the questionnaires were able to respond and return the copies. The survey questions were divided into six categories. The first group of 
questions dealt on the effort made by the library to introduce services to the new entrants to the institutions. The next set of questions dealt on the publicity undertaken by the library to create awareness generally. Then, questions were asked based on the interaction between the faculty and the library. The rest of the questions were on the level of co-operation with the faculty, involvement of information technology and the evaluation of library skill instruction efforts at these institutions.

Since the gathering at this venue was a good opportunity to have immediate access to librarians in universities, thirty three questionnaires were given out. They were successfully collected and used for analysis.

\section{DATA ANALYSIS AND RESULT}

The result of the survey showed that all universities in Nigeria make provision for library skill instruction for fresh students. This is mostly done when the students' programme of orientation is taking place. Other training sessions offered to the students in $76 \%$ of the institutions are variously tagged library tour or library orientation talk. Only $13 \%$ of the responding institutions offer demonstration about the library on CD ROM.

On the publicity given to the library to create awareness, $82 \%$ of the 33 universities sampled do not provide library guide while only $19 \%$ did. Less than half $(46 \%)$ provide point of use instructions and posters. On how these libraries introduce their services to the institutions community, $40 \%$ present welcome speech and provide handout about the library and $60 \%$ do not provide such. Library newsletter to highlight library services and collections are only provided by $55 \%$ of the institutions. On how often the libraries received requests to organize special tours and orientation from departments, $66 \%$ have received such requests while $44 \%$ never received. In $69 \%$ of the institutions the students are compelled to take a research component in their studies in which they make effective use of the library. It is only in $43 \%$ of the institutions that this course is graded.

In all institutions, library instruction is not offered as a course or credit carrying course but comes up generally as part of general studies course. There is variation in all these institutions on the number of times library instruction course is taught. In $76 \%$ of the institutions, it comes up once while in $16 \%$ of the institutions it comes up all through the sessions of the students' life in the school. The library instructors do not have absolute control over the course hence the number of lecture period allocated is dependent on the provisions made by the co-coordinating faculty. On level of co-operation received from the faculty as regards scheduling the library instruction sessions, in $68 \%$ of the institutions, the relationship has not been so cordial. It seems that there is little or no co-operation as the teaching faculty would wish to handle the library instruction sessions. Only $32 \%$ of the institutions libraries received encouraging co-operation from the faculty. In $63 \%$ of the institutions, the library skill instructors are not involved in grading the examination papers on use of library.

These university libraries have reached some level of compliance on information technology usage. $38 \%$ of the institutions have reached appreciable level, while only $13 \%$ has reached $70 \%$ level in library automation. Not minding the level of compliance reached, in $77 \%$ of the institutions, the students are carried along at every level of development. From the opinion of the respondents, the provision of library skill instruction so far has been effective in $69 \%$ of the institutions. $29 \%$ claim that information technology has not been effective in their institutions. On the impact information technology has had on the library use, $85 \%$ stated that it has had only little impact. While $15 \%$ claim it had no impact at all.

\section{DISCUSSION}

This survey shows that in Nigerian tertiary institutions there is clear awareness of the need for library skill instruction. The teaching of this course has been integrated into the teaching of general studies. Freshmen are exposed to orientation talks and library tours. Since these teachings are not graded, students' participation has not shown the required level of commitment.

There are materials that are put in place to help advertise the library services which enable the users find their ways easily when they use the library. Majority of the libraries surveyed provide library brochure that gives information about the services offered. Slightly below majority go further to provide poster or library newsletter. Libraries need to make effort to enable users find materials independently. This will mean that at graduation, students must have acquired enough library skill to enable them use any library freely. However, the findings here show that librarians have encountered graduate students who could not use the library effectively. Librarians often receive requests from faculties for their students to be taken on special tour of the libraries. Such 
requests give students opportunity to understand the method of use of library services clearly.

Conflict between the library and the faculty still arises occasionally. A major area of conflict is in allocation of library skill instruction period on the schedule for time table. Librarians are not the ones that draw the time tables and only depend on the periods allocated to them. As reported in earlier studies, librarians are not involved in grading the papers even after teaching the course. This is found to be true in this report. Introduction of research component in library skill instruction where students are expected to make use of this library has not been worked out effectively. In some cases, library skill instruction comes up to the students just once during their education period as students. Very few librarians are involved as instructors in co-coordinating this library skill instruction course in the universities. In many of these institutions, the library has not received full co-operation from faculties as regards scheduling of library instruction sessions. They often want to do the teaching themselves. In very few cases where the librarians are given free hand to co-ordinate this course, the output has had a marvelous effect. Majority of the librarians agree that provision of library instruction has been effective generally. Its impact has greatly been noticed during students' research activities. The students could work independently in locating vital information. Library skill instruction has had remarkable impact on the use of library in these institutions surveyed. It is also discovered that where library skill instruction sessions are well attended, the problem of large class could not allow proper assessment of students' assimilation rate.

The level of information technology compliance in these institutions is still below average (40\%). In most institutions, the students and staff seem to be carried along. However, there are cases where many librarians do not have knowledge of the level developments in information technology has gotten to in their institutions. This is a dangerous situation as the absence of the few individuals who handle these equipments will create a serious setback. However, universities who have access to information technology have enjoyed the benefits.

\section{CONCLUSION}

Academic library instruction in Nigerian universities though largely developed has a lot of problem to grapple with. Firstly, the librarians do not have direct control over the students and often do not come in contact with them many times in their stay in the institutions. Librarians' effort to boost the image of the library has to be followed aggressively. Librarians should not be deterred because of difficulties encountered. The benefits of these efforts should spur more effort to forge ahead since the results are highly encouraging.

This paper recommends more management support for librarians' effort to teach library skill. This can be by provision of adequate classrooms, sustenance of credit-earning capacity of the course and compulsory nature of a 'pass' in the grading system among others. The information technology aspect of library skill needs to be intensified; Information technology is penetrating every sphere of life. Any problem that hinders adequate knowledge of proper use of the library could keep the student behind others worldwide.

\section{REFERENCES}

Ajibero M. I., 1995. User expectation from Nigerian University Libraries Services in the $21^{\text {st }}$ Century. Public and Access Services Quarterly 1: $33-49$.

Adedigba, Y., 1990. User Education in research institutes libraries in Nigeria. Quarterly bulletin of the International Association of Agricultural Librarians and Documentation. 35. pp. $73-76$.

Awale - Ale, Isabella Idomu,. 2007. Faculty Librarian Collaboration on developing reading skills in Tertiary institutions. Library philosophy and practice 2007. (paper presented at the $3^{\text {rd }}$ Annual ELTT National Conference held at Senate Chamber University of Agriculture (UNAAB). Abeokuta Oct. 5- 72005.

Barbara, Francis, Gleen James, Lee Kate, Chair Alice Primack, and Sanderson Rosalie. 1992. Evaluation of the library instruction program at the University of Florida. Libwebmaster@mail.uflib. Ufl.edu last updated April 42008.

Castello, B. Lenholt, R and Stryker, J., 2004. Using black board in library instruction: addressing the learning style of generation $X$ and $Y$, Journal of academic liblibrarianship. 30: 452-60. 
Cross, Melissa, 2005. The impact of low - level skills on information seeking behaviors. Reference and User Services Quarterly 45, (2): $155-62$.

Edem, Nkoyo, Ani Okon and Ocheibi Jonathan, 2009. Students' perceived effectiveness in the use of library resources in Nigerian universities. Educational Research and Review 10, (6): $322-326$.

Emmaris, Mark and Wanda, Martin. 2002. Engaging conversation, evaluating the contributions of library instruction to the quality of students research. College and research libraries 63, (6): 545-560.

Gandlri, S., 2004. Faculty librarian collaboration to access the effectiveness of a five session library instruction model. Community and Junior College Llibraries, 12: 15-48

Ghaphery, James.2002. My library at Virginia Commonwealth Library. D._Lib Magazine 8: $(7 / 8): 1-7$.

Gong, Xiaome and Loomis, Mary Kay., 2009. An Empirical study on following library instruction sessions in the classroom. Electronic journal of Academic and special librarianship 10,(1): 1 - 13.

Griffiths, Jullian R. and Peter, Brophy., 2005. Students Searching behaviour and the Web: Use of academic Resources and google. Library Trends. 53(4): 537 - 554.

Hovde, K., 2000. Check the citation: Library Instruction and Student paper bibliographies. Research Strategies 17 (1): 3-9.

Hurst, Susand and Leonard, Joseph, 2007. Garbage in, Garbage out the effect of library instruction on the quality of students' term paper. Electronic Journal of Academic and special librarianship 8 (1): 1-13,
Iroka, L., 1990. Library orientation and instruction for students in Nigerian Medical Schools. Research Strategies 8: $82-84$.

Lorenzen Michael, 2004. Library Instruction outside North America. America in the $20^{\text {th }} \quad$ Century. www.libraryinstruction.com/international. html.

Maness, Jack, 2008. Evaluation of Library Instruction delivery to Engineering Students using streaming Video. <jack.maness@colorado.edu.

Martin, Jasen, 2008. The Information seeking behaviour of undergraduates education majors: Does library instruction play a role? Evidence based library and information practice 3: (4) 4-17.

Maybee, C., 2006. Undergraduate perception of information use: the bases for creating user - centered student information literacy instruction. Journal of Academic librarianship. 32: 79-95

Nwoye, S. C. and Anafulu, J.C., 1973. Instructing University Students in Library use: The Nsukka experiment. Libri $23: 251$ - 259.

O'Brien, Heather L and Songa Symons, 2005. The information Behaviour and preference of undergraduate students. Research Strategies 20 (4): 409 - 423.

Robinson, Andrew and Schlegl Karen., 2004. Student Bibliographies improve when professors provide enforceable guideline for elations. Portal: libraries and the Academy 4. (2): 275-290.

Todd, Ross J., 2003. Adolescents the information seeking and use implications for information professionals. School Libraries Worldwide 9.(2): 27 - 46 


\section{APPENDIX 1}

PERCENTAGE ANALYSIS OF ANSWERS RECEIVED

Yes

No

Information provided to users during orientation

Other training Sessions

Use of Library (General Studies)

C.D. Rom Demonstration

Publicity to Create Awareness

Provision of Library Guides

Point of us Instruction(@reception/circulation)

Introduction of the Library to the user Community

Welcome Speech/Handout

Library Newsletter

Request from faculty to organize orientation

Component of study involving use of library

Course taught more than once in the life of a student

Co-operation received from Faculty

Cordial

Not Cordial

Instructor involved in grading exam papers
$100 \%$

$76 \%$

$13 \%$

$24 \%$

$87 \%$

$19 \%$

$81 \%$

$46 \%$

$54 \%$

$40 \%$

$55 \%$

$66 \%$

$69 \%$

$75 \%$

$32 \%$

$68 \%$

$37 \%$

$63 \%$

\section{INVOLVMENT IN ‘ T’}

Level of compliance reached in IT

$38 \%$ of the Libraries reached $20 \%$ compliance

$4 \%$ of the Libraries reached $50 \%$ compliance

$6 \%$ of the Libraries reached $70 \%$ compliance

$13 \%$ of the Libraries reached above $70 \%$ compliance

Students and Staff carried along

$77 \% \quad 23 \%$

Effectiveness of provision of library instruction

$69 \% \quad 31 \%$

Level of effectiveness of IT

$71 \% \quad 29 \%$

Impact of IT on Library use

$85 \% \quad 15 \%$ 